Digitalizacja archiwalnych numerów czasopisma naukowego Analecta Cracoviensia 1-24 (1969-1992) i ich publikacja w otwartym dostępie - zadanie finansowane w ramach umowy 672/P-DUN/2017 ze środków Ministra Nauki i Szkolnictwa Wyższego przeznaczonych na działalność upowszechniającą naukę

ANALECT A CRACOVIENSIA 4 (1972) 217-238

\title{
WSPÓŁCZESNA ANTROPOLOGIA PRAWOSŁAWNA
}

Już w r. 1936 N. Bierdiajew pisał, że ,,problem człowieka jest centralnym dla świadomości naszej epoki" 1. Myśl współczesna, jego zdaniem, stoi przed wielkim zadaniem zbudowania antropologii chrześcijańskiej (zwłaszcza filozoficznej) jako odrębnej dyscypliny ${ }^{2}$. Wielu współczesnych autorów prawosławnych podziela to przekonanie uważając, że antropologia chrześcijańska nie została jeszcze wystarczająco usystematyzowana i opracowana. Przyznają oni, że również w teologii prawosławnej nie ma dotąd szczególowego i ogólnie przyjętego opracowania antropologii ${ }^{3}$.

W ostatnich latach temat antropologiczny znalazł się w samym centrum refleksji ekumenicznej. Również teologowie prawosławni tej miary co P. Evdokimov ( $\dagger$ 1970), J. Meyendorff, O. Clément i N. Nissiotis odpowiedzieli na tę potrzebę czasu wzmożonym zainteresowaniem problematyką człowieka, dostrzegając w niej głównie locus theologicus naszego czasu. Podkreślają oni wielkie znaczenie i aktualność antropologii chrześcijańskiej ze względu na następujące racje:

1. Myśl współczesna przechodzi obecnie przez okres głębokich przemian w rozumieniu człowieka. Źródłem ich jest $\mathrm{m}$. in. nieustanny postęp w dziedzinie badań naukowych nad człowiekiem. Współczesne prądy sekularyzacyjne bazują na antropologii, która wyklucza wszelką ideę transcendencji w sensie religijnym, zastępując ją swoistym horyzontalizmem antropologicznym oraz optymizmem futurologicznym. Współczesna wiedza o człowieku przeniknięta jest założeniami metody opisowo-

1 N. Bierdiajew, Problema cziełowieka (K postrojeniju christianskoj antropotogii). ,Put”" 50 (1936) 3.

2 Tamże, s. 4.

3 Por. V. Lossky, La conscience catholique. Implications anthropologiques du dogme de l'Église, „Contacts” 42 (1963) 77 (76-88); V. Zenkowsky, Das Bild vom Menschen in der Ostkirche. Grundlagen der orthodoxen Anthropologie. Stuttgart 1951, 14. 
-eksperymentalnej, która sprawia, że studium człowieka staje się jedynie opisem tego co w nim bezpośrednio uchwytne i sprawdzalne. Problemy antropologii klasycznej (np. sumienie, związek między duszą a ciałem, stworzenie człowieka, śmierć) stały się mniej uchwytne dla współczesnego umysłu. Zainteresowanie zwraca się raczej do takich problemów jak: stosunek autorytetu do wolności osobistej, konflikty rasowe, konflikt między narodami bogatymi i ubogimi, między jednostką a społeczeństwem oraz między ciągłością historyczną a rewolucyjną, wyzwolenie człowieka ${ }^{4}$.

2. Teologowie prawosławni zdają sobie sprawę, że również $w$ dziedzinie współczesnej teologii dokonuje się wyraźny zwrot antropologiczny. Sprawia on, że w ujęciu niektórych autorów nadzieja teologalna zbliża się do czysto ludzkiego optymizmu futurologii antropologicznej, że proces sekularyzacji usprawiedliwiany jest w świetle nauki o Wcieleniu, że prawdziwego humanum poszukuje się wyłącznie w. samym człowieku ${ }^{5}$. Niektórzy teologowie prawosławni wyrażają obecnie gotowość do dialogu na temat, $w$ jakiej mierze cała teologia chrześcijańska jest i powinna być antropologią. Warunkiem tego dialogu jest według nich przyjęcie w punkcie wyjściowym otwa rtego poglądu na człowieka jako istotę ,,absolutnie otwartą ku górze”, której prawdziwe wymiary ukazują się najpełniej w osobie Jezusa Chrystusa ${ }^{6}$.

3. Antropologia chrześcijańska oparta na ewangelicznych podstawach powinna, zdaniem teologów prawosławnych, dopomóc człowiekowi współczesnemu zrozumieć jego prawdziwe wymiary. W tym celu musi ona przede wszystkim spełnić funkcję krytyczną $\mathrm{w}$ stosunku do rozpowszechnionych poglądów na człowieka. Musi odrzucić szereg dogmatów sekularystycznych, m. in. takich jak absolutna autonomia człowieka, kosmocentryzm i ,sociomagnetyzm" 7. Zadaniem teologii jest wziąć na serio wszystkie nowe tendencje antropologiczne i humanistyczne we współczesnym świecie; musi ona respektować ludzki postęp i rozwój. $\mathrm{Z}$ drugiej strony jednak nie może ona utożsamiać się z różnymi formami humanizmu, opartego jedynie na badaniach nauk eksperymentalnych, który nie zna wartości osoby ludzkiej w jej relacji do Boga. Specyficz-

4 Por. N. A. Nissiotis, La question de l'homme. Evoluation théologique de quelques approches contemporaines, „Contacts" 69 (1970) 7-16 (7-31); J. Meyendorff, Orthodox Theology Today, „St. Vladimir's Theological Quarterly” 13 (1969) 77—92, zwł. s. 84.

5 Nissiotis, dz. cyt., 22. Por. J. Meyendorff, Unity of the Church - Unity of Mankind, "The Ecumenical Review" 24 (1972) 30-46.

6 Meyendorff, Ortodox Theology, art. cyt., 84-86; tenże, Le Christ dans la theologie byzantine, Paris 1969, 289-290.

7 Meyendorff, Ortodox Theology, dz. cyt., 84. 
nym zadaniem antropologii chrześcijańskiej jest rozróżnianie i ocenianie znaków czasu oraz wszelkich zmian w rozumieniu człowieka ${ }^{8}$.

4. Antropologia chrześcijańska posiada ogromne znaczenie dla całej reszty teologii. Analiza kontrowersji dogmatycznych wykazuje, że w ostatecznej instancji opierają się one na różnych sposobach rozumienia człowieka, jego aktywności i przeznaczenia. Fakt ten ukazuje ekumeniczną wartość teologicznej refleksji nad człowiekiem. B. Zenkowsky oświadcza wręcz, że tak długo będzie nam trudno dojść do zbliżenia wyznań chrześcijańskich w dziedzinie dogmatycznej, dopóki nie uda się osiągnąć jednakowej koncepcji człowieka oraz jego historycznej działalności ${ }^{9}$. Specyficzna rola antropologii prawosławnej wynika z faktu, że kształtowała się ona w pogodniejszej i bardziej optymistycznej atmosferze niż antropologia Kościoła zachodniego ${ }^{10}$. Dzięki temu może ona wnieść do dialogu o człowieku swoiste wartości religijne.

W niniejszym studium chodzi jedynie o szkicowy zarys współczesnej antropologii prawosławnej (zwłaszcza rosyjskiej i greckiej), która korzeniami swymi sięga do nauki wschodnich Ojców Kościoła i precyzuje się coraz bardziej w naszych czasach. Omówienie jej źródeł, podstaw oraz głównych rysów pozwoli z kolei podkreślić w zakończeniu możliwy wkład myśli prawosławnej we współczesną refleksję teologiczną nad człowiekiem.

\section{I. ŹRÓDEA ANTROPOLOGII PRAWOSEAWNEJ}

Według jednomyślnego przekonania myślicieli prawosławnych tekst biblijny o stworzeniu człowieka ,na obraz i podobieństwo Boże” ( $R d z 1$, 26-28) posiada zasadnicze $i$ istotne znaczenie dla antropologii chrześcijańskiej. Znajduje on swe wyjaśnienie i dopełnienie w całym Piśmie

8 Nissiotis. dz. cyt., 22-23. Na krótko przed drugą wojną światową S. Bułgakow pisał: „Der Mensch von heute leidet und seufzt unter dem Mangel einer richtigen Lehre vom Menschen, einer christlichen Anthropologie", Die christliche Anthropologie, w: Kirche, Staat und Mensch, Genf 1937, 254 (209-255). Krótko po wojnie archim. Kiprian z Paryża pisał o współczesnym „znieważaniu osoby ludzkiej” oraz o „herezji braku ludzkości” (jeres' bezcziełowiecznosti) uważając je za "crimen laesae humanitatis"; obrona osoby ludzkiej przed wszelkimi tendencjami do pomniejszania człowieka jest, wg niego, jednym $\mathrm{z}$ istotnych zadań chrześcijaństwa: ,... christianskoje soznanije i dołżno, osobienno w naszie wriemja, skazat' swoje weskoje u włastnoje słowo o cziełowiekie. Cziełowiek, w jego fiłosofskom i bogosłowskom ponimanii, nużdajetsja w naszi dni w osoboj zaszczitie". Kiprian (Kern), Tema o czietowiekie $i$ sowriemiennost,. „Prawosławnaja Mysl” 6 (1948) 125-137 cyt. s. 130.

9 Zenkowsky, dz. cyt., 8; L. A. Zander, Vision and Action: The Problems of Ecumenism, London 1952, 58.

${ }_{10}$ W dziejach swojej myśli teologicznej Wschód chrześcijański nie znał pelagianizmu; jego teologia wolna była od wszelkiego lęku przed tym niebezpieczeństwem, ustawicznie zagrażającym myśli zachodniej, która kształtowała się pod dominującym wpływem św. Augustyna. Por. Zander, dz. cyt., 57-58. 
świętym, które mówi o człowieku zbawionym i przemienianym przez Boga ${ }^{11}$.

Obok Pisma świętego podstawowym źródłem antropologii prawosławnej jest nauka wschodnich $\mathrm{O}$ jcó $\mathrm{w}$ Kości oła. Zajmując się przede wszystkim dogmatem trynitarnym i chrystologicznym, Ojcowie ubocznie poruszali również tematy antropologiczne. Opierali się oni głównie na nauce Pisma świętego, a równocześnie usiłowali przystosować główne pojęcia filozofii platońskiej do podstawowych prawd chrześcijańskiej doktryny o człowieku. Jakkolwiek Ojcowie greccy nie opracowali systematycznej nauki o człowieku, niemniej jednak rozwinęli szereg zagadnień antropologicznych leżących u podstaw antropologii prawosławnej, m. in. naukę o "otwartej”, wolnej i zdolnej do transcendencji (epektasis) naturze człowieka, o tajemnicy obrazu i podobieństwa Bożego w człowieku oraz o jego przebóstwieniu (theosis) ${ }^{12}$. Najbardziej oryginalne i twórcze są pod tym względem poglądy św. Ireneusza, Klemensa Aleksandryjskiego, Orygenesa, Atanazego Aleksandryjskiego, Ojców kapadockich, a zwłaszcza św. Grzegorza z Nysy, Cyryla Aleksandryjskiego, Maksyma Wyznawcy oraz Jana Damasceńskiego ${ }^{13}$.

Rozpatrywana od strony swoich źródeł patrystycznych, współczesna antropologia prawosławna stanowi jedynie przedłużenie i rozwinięcie nauki Ojców w duchu twórczej wierności względem ich podstawowych intuicji antropologicznych. Główne idee antropologii patrystycznej były przedmiotem analiz teologicznych, podejmowanych zwłaszcza przez myślicieli rosyjskich i greckich. Ci ostatni poprzestawali najczęściej na analizie tekstów biblijno-patrystycznych, natomiast wielu prawosławnych teologów i filozofów rosyjskich dążyło do reinterpretacji ujęć tradycyjnych oraz do opracowania szerszej syntezy antropologicznej ${ }^{14}$. Przeważająca część myślicieli rosyjskich (m. in. L. Šiestow, N. O. Lossky,

11 Por. m. in. Bułgakow, dz. cyt., 221; P. Bratsiotis, Genesis 1, 26 in der orthodoxen Theologie, „Evang. Theologie” 11 (1951-52) H. 7-8, 289-297; J. Karmiris, Abriss der dogmatischen Lehre der orthodoxen Kirche, w: Die orthodoxe Kirche in griechischer Sicht, Stuttgart 1959, 41 (15-120).

$12 \mathrm{Na}$ temat patrystycznej koncepcji obrazu bożego w człowieku por. $m$. in. Z. C. Kintaras, Man - the image of God according to the Greek Fathers: kat'eikona kai kath omoiosin, "The Greek Orthodox Theological Review" 1 (1954) 48-62; V. Lossky, A l'image et à la ressemblance de Dieu, Paris 1967, 123-137; tenże, Théologie mystique de l'Église d'Orient, Paris 1944 (1960), 109-129. Na temat idei przebóstwienia w nauce Ojców greckich por. zwłaszcza M. Lot-Borodine, La déification de l'homme selon la doctrine des Pères grecs, Paris 1970; A. Theodorou, Die Lehre von der Vergottung des Menschen bei den griechischen Kirchenvätern. Ein Überblick, „Kerygma und Dogma” 7 (1961) 283-310.

13 Sw. Grzegorz z Nysy w De hominis opificio podał pierwszy zarys antropologii teocentrycznej, zapoczątkowanej już przez Klemensa i Atanazego Aleksandryjskiego; poglądy św. Grzegorza znalazły żywy oddźwięk w twórczości N. Bierdiajewa.

14 Już G. Skoworoda (1722-1794), później zaś P. Jurkiewicz (1827-1874) wychodząc z biblijnego pojęcia ,serca" rozwinęli swoisty typ metafizyki „człowieka prawdziwego", otwartego na działanie „energii bożych". 
N. Bierdiajew, S. Frank i S. Bułgakow) podejmowała próbę powiązania antropologii z chrystologią celem stworzenia antropologii teandrycznej ${ }^{15}$.

Myśl patrystyczna do dzisiaj nie przestała stanowić głównego natchnienia dla antropologii prawosławnej, dążącej do świadomego zakorzenienia w „wielkiej Tradycji” chrześcijańskiej. Powołuje się ona jednak nie tylko na spekulatywne traktaty teologicznej Ojców i pisarzy Kościoła, lecz również na doświadczenia wielkich ascetów i mistyków Kościoła wschodniego (tzw. antropologia hagiofaniczna), takich np. jak Makary Egipski, Izaak Syryjczyk, Pseudo-Dionizy Areopagita, św. Symeon Nowy Teolog (949-1022) oraz św. Grzegorz Palamas († 1359) ${ }^{16}$.

Doniosłym źródłem antropologii prawosławnej jest również lit u rg i a, ukazująca człowieka w świetle misterium Chrystusa jako ,istotę liturgiczną” i „pneumatoforyczną”, zdolną do adoracji, modlitwy i służenia ${ }^{17}$. Szczególne znaczenie posiada pod tym względem dla antropologii święto Paschy, odznaczające się niezwykłym bogactwem treści teologicznych i mistycznych, naświetlających tajemnicę człowieka oraz jego ostatecznego przeznaczenia ${ }^{18}$.

U podstaw współczesnych dążeń do opracowania antropologii prawosławnej leży z jednej strony świadomość niewystarczalności antropologii czysto humanistycznej, z drugiej natomiast przekonanie, że tradycyjna nauka o człowieku wymaga obecnie twórczego przemyślenia w świetle nowych problemów ${ }^{19}$.

15 Scisły związek z głównymi tematami antropologii patrystycznej uwidacznia się również u autorów dawniejszych, np. u A. Chomiakowa, J. Kirejewskiego, N. Fiodorowa, T. Gołubińskiego, M. Tarejewa, W. Sołowiewa, S. Trubeckogo, L. Karsawina, a nawet (na swój sposób) u F. Dostojewskiego i N. Gogola. Już w XIX w. śmiałą próbę antropocentrycznego ujęcia filozofii i teologii podjął V. Niesmiełow (1863-1920), profesor Akademii Kazańskiej, w dwutomowym dziele Nauka o człowiekie, Kazań 1896, 1903 (w tym kierunku ustawiła go już jego teza doktorska na temat Dogmatycznego systemu św. Grzegorza $z$ Nysy, Kazań 1887). Tendencja antropocentryczna występuje także w poglądach metr. Antoniego (Chrapowickiego), zwłaszca zaś w religijno-filozoficznym systemie N. Bierdiajewa. W poglądach wielu rosyjskich myślicieli prawosławnych (m. in. u W. Sołowiewa, L. Karsawina, B. Wysziesławcjewa, N. Bierdiajewa, S. Bułgakowa i B. Zieńkowskiego) przeważają elementy filozoficzno-spekulatywne, personalistyczne i egzystencjalne.

16 Por. Archim. Kiprian (Kern), Antropołogia św. Grigorija Pałamy, Pariż 1950 .

17 Zob. P. Evdokimov, L'Orthodoxie, Neuchâtel 1959; tł. pol. Prawosławie, Warszawa 1964, 107-109; Zenkowsky, dz. cyt., 7-8, 10-11; O. Clément, L'homme comme lieu théologique, "Contacts" 68 (1969) 290-305, zwł. s. 295; J. Romanides, Man and his True Life According to the Greek Orthodox Service Book, "The Greek Orthodox Theological Review" 1 (1954) 63-83.

18 Zenkowsky, dz. cyt., 10-11.

19 Bierdiajew, dz. cyt., 4; Lossky, La conscience catholique, art. cyt., 77. 


\section{G£ÓWNE PODSTAWY TEOLOGICZNO-FILOZOFICZNE} ANTROPOLOGII PRAWOSEAWNEJ

Kościół prawosławny nie zna ścisłego rozgraniczenia między antropologią filozoficzną i antropologią teologiczną. Filozofia prawosławna jest filozofią religijną, ściśle związaną z dogmatem. Wskutek tego filozoficzna myśl Kościoła prawosławnego jest $\mathrm{z}$ istoty swej religijna również i w dziedzinie antropologii. Nie uznaje on antropologii filozoficznej, która nie byłaby zarazem antropologią chrześcijańską i mistyczną. $\mathrm{Z}$ tej racji antropologia prawosławna ma swoje podstawy zarówno w teologicznej jak i filozoficznej refleksji nad człowiekiem.

\section{Dogmat trynitarny i chrystologiczny}

Kluczem do antropologii prawosławnej jest dogmat Trójcy świętej. Samo pojęcie osoby precyzowało się najpierw w kontekście trynitarnym, a dopiero po Soborze chalcedońskim (451) przeszło do chrystologii i antropologii.

Prawosławie buduje swą antropologię odgórnie, wychodząc z dogmatu trynitarnego i chrystologicznego, aby następnie odkryć w rzeczywistości ludzkiej jedność natury i wielość hipostaz stworzonych ${ }^{20}$. Osobą w sensie absolutnym jest tylko Bóg, wszelka zaś osoba ludzka jest jedynie Jego „obrazem i podobieństwem”. Według formuły chalcedońskiej obydwie natury Chrystusa są zjednoczone „w jednej osobie i hipostazie Syna" (eis hen prosopon kai mian hypostasin). Obydwa terminy określające osobę (prosopon i hypostasis) posiadają właściwy sobie odcień znaczeniowy. Prosopon oznacza psychologiczny aspekt bytu zwróconego ku swemu wnętrzu, a więc psychiczny jednoczący ośrodek jaźni, czyli świadomość siebie. Hypostasis wyraża natomiast aspekt bytu otwartego i transcendującego swój własny świat wewnętrzny w kierunku Boga. Ten drugi aspekt jest według antropologii prawosławnej decydujący dla teologicznego opisu osoby ludzkiej oraz dla zrozumienia jej struktury teandrycznej ${ }^{21}$. Tajemnica osoby jako hipostazy zawarta jest $\mathrm{w}$ jej otwartości i zdolności do transcendencji, tj. wyjścia $\mathrm{z}$ samej siebie ku Bogu, w którym każda Hipostaza istnieje wyłącznie ku Drugiej.

20 P. Evdokimov, Mystère de la personne humaine, „Contacts” 68 (1969) 283, 289 (272-289); Bułgarow, Die christliche Anthropologie, dz. cyt., 224, 238-240; Clément, art. cyt., 293; Bierdiajew, art. cyt., 4. Ponieważ antropologia prawosławna kształtuje się odgórnie, w oparciu o dogmat trynitarny i chrystologiczny, dlatego antropologia naukowa, oparta na obserwacji konkretnych faktów, posiada dla teologa, zdaniem Losskiego, drugorzędną wartość (La conscience catholique, art. cyt., 78). O potrzebie zbiżenia obydwu antropologii pomimo ich odrębnych zadań, por. Nissiotis, art. cyt., $26-27$.

21 Evdokimov, Mystère..., art. cyt., 285, 288. Bułgakow zwraca uwagę, że dogmat chalcedoński należy nie tylko do chrystologii, lecz w równej mierze do ontologii. Die christliche Anthropologie, dz. cyt., 250. Por. także V. D. Sarychev, Christologie et antropologie chrétienne, „Istina” 13 (1968) 456-463. 
Ponieważ człowiek został stworzony na obraz i jako podobieństwo Trójjedynego Boga, prawosławie widzi w dogmacie Trójcy świętej główną podstawę antropologii chrześcijańskiej ${ }^{22}$. Misterium potrójnej osobowości Boga w jednej naturze znajduje odbicie w misterium człowieka. Prawdziwy i doskonały obraz boży wymaga przezwyciężenia wzajemnej opozycji oraz różnorodności osób posiadających tę samą naturę. W miarę jak człowiek realizuje w sposób doskonały swoją ludzką naturę wspólną wszystkim ludziom oraz personalizuje ją w sobie, nie jest odizolowany ani oddzielony od drugich ani skazany na relacje czysto zewnętrzne. Pozostając w pełni sobą przyczynia się do urzeczywistnienia ,wielojedności" (mnogojedinstwa) rodzaju ludzkiego, a nawet stanowi jedno z całą ludzkością ${ }^{23}$. Ponieważ istnieje jeden Bóg w trzech różnych Hipostazach, dlatego również w wielości poszczególnych osób istnieje jedna ludzkość jako ontyczna całość ${ }^{24}$.

Pojęcie jedynej w swoim rodzaju, niesprowadzalnej do niczego rzeczywistości osoby ludzkiej oraz idea ontycznej jedności wszystkich ludzi solidarnie związanych $\mathrm{z}$ całym kosmosem - oto dwa komplementarne bieguny antropologii prawosławnej ${ }^{25}$.

Z nauką o ontycznej jedności całego rodzaju ludzkiego teologia prawosławna wiąże również pojęcie s o bo rności (sobornost') natury ludzkiej, odgrywające bardzo doniosłą rolę zwłaszcza w religijnej myśli rosyjskiej ${ }^{26}$. Według niej podmiotem wolności i osobowej świadomości jest człowiek nie jako jednostka, lecz jako rzeczywistość stanowiąca jedność z Chrystusem oraz innymi ludźmi. Swiadomość ludzka jako taka posiada charakter ponadindywidualny, wspólnotowy (sobornyj) i ,katolicki" (w pierwotnym znaczeniu tego terminu: kath 'olon = według całości) ${ }^{27}$. Aby wyrazić tę myśl, teologowie i filozofowie prawosławni

22 Por. O. Clément, L'Église orthodoxe, Paris 1965, 61; tenże, L’homme comme lieu théologique, art. cyt., 293; tenże, Questions sur l'homme, Paris 1972, 29-52.

23 Idea "wielojedności" stanowi główny wątek filozofii religijnej W. Solowiewa. Zob. "W. Szylkarski, Solowjews Philosophie der All-Einheit, Kaunas 1932; V. Zeńkowskij, Ideja. wsiejedinstwa $w$ fiłosofii Władimira Sołowiewa, „Prawosiawnaja Mysl" 10 (1955) $45-59$.

24 Nauka o ontycznej jeđności natury ludzkiej, oparta na przesłankach biblijnych $(R z 5,12-19)$ i patrystycznych (por. Grzegorz z Nysy, De hominis opificio 16; $P G 44,186$-187), stanowi podstawę dla prawosławnej doktryny o udziale wszystkich ludzi w upadku pierwszego człowieka oraz o potencjalnym odkupieniu i przebóstwieniu natury ludzkiej w człowieczeństwie Chrystusa (koncepcja rozwinięta głównie przez metr. Antoniego Chrapowskiego, S. Bułgakowa i L. Karsawina). W tym znaczeniu antropologia rosyjska mówi o ,wszechczłowieczeństwie" (wsjecziełowiecziestwo) Chrystusa i każdego człowieka. Terminem tym posługuje się zwłaszcza S. Bułgakow. Por. Niewiesta Agnca, Pariż 1945, 114-135.

${ }_{25}$ Zenkowsky, dz. cyt., s. 42-53; Bułgakow, Die christliche Antropologie, dz. cyt., $226-228$.

26 Por. Zenkowsky, dz. cyt. $30-42$; tenże, La „sobornost'” dans la nature de l'homme, „Dieu vivant” 27 (1935) 91-104.

27 Stanowi to podstawę dla tajemnicy ,soborowości” Kościoła, w którym człowiek jest sobą przez wspólnotę $\mathrm{i}$ we wspólnocie $\mathrm{z}$ drugimi. Treść tę usiłuje wyra- 
często posługują się formułą S. Trubeckogo: „w nas samych odbywamy naradę (sobor) ze wszystkimi" ${ }^{28}$. Przez swoje ciało człowiek pozostaje w ścisłej łączności i zależności od całego kosmosu. Dzięki temu soborność natury. ludzkiej nabiera charakteru kosmicznego: ciało jest narzędziem bezpośredniego działania w świecie oraz warunkiem twórczego uczestnictwa w przemianie kosmosu ${ }^{29}$.

Nauka o soborności natury ludzkiej stała się jedną z głównych podstaw prawosławnego personalizmu wspólnotowego, który głosi ideę przetwarzania społeczeństwa ludzkiego w prawdziwą wspólnotę osób na wzór Trójcy świętej ${ }^{30}$.

2. Wschodnia koncepcja przyczynowości i uczestnictwa

Elementy filozoficzne antropologii prawosławnej zaczerpnięte są przede wszystkim z tradycji platońskiej. Zasadnicza różnica między antropologią wschodnią i zachodnią polega na tym, że opierają się one na dwóch różnych koncepcjach przyczynowości i uczestnictwa. Podczas gdy tradycja zachodnia akcentuje bardziej przyczynowość sprawczą, tradycja orientalna posługuje się na pierwszym miejscu kategoriami uczestnictwa oraz przyczynowości formalnej ${ }^{31}$. Nawiązując do myśli platońskiej pojmuje ona rzeczywistość jako uczestnictwo w Bogu po linii przyczynowości formalnej i w kategoriach podobieństwa. Swiat według niej jest rzeczywistością symboliczną, pewnego rodzaju epifanią wyższego porządku i wyrazem Boga. Wszystkie rzeczy zawierają w sobie podobieństwo do Boga. Pojęcie „partycypacji w życiu bożym” jest jedną z podstawowych idei antropologii prawosławnej. Zakłada ono, zdaniem J. Meyendorffa, wzajemne przenikanie się Bytu Bożego i ludzkiego, ich wzajemną ,otwartość”. Jako Osoba żyjąca i działająca, Bóg jest „otwarty” względem egzystencji stworzonej, zwłaszcza ludzkiej. Ze swej strony, człowiek nie jest istotą autonomiczną i zamkniętą $w$ sobie, lecz bytem teocentrycznym i ,otwartym", jego prawdziwe życie jest w Bogu, „który sam posiada nieśmiertelność". Uczestnictwo człowieka w życiu Bożym nie narusza w żaden sposób jego autentycznie ludzkiej egzystencji ${ }^{32}$.

zić angielski i francuski przekład wyrazu "sobornost”" przy pomocy terminu „togetherness" oraz „conciliarité".

28 Por. B. Zenkowsky, Histoire de la philosophie russe, Paris 1954, t. II, 355.

29 Zenkowsky, Das Bild..., dz. cyt., 48-53; Bułgakow, Die christliche Anthropologie, dz. cyt., 229-230, 232-233.

30 Hasłem tego kierunku były słowa N. Fiodorowa: „Dogmat Trójcy świętej jest naszym programem społecznym". Głównym jego przedstawicielem był $\mathrm{m}$. in. N. Bierdiajew, który z kolei wywarł duży wpływ na personalizm francuski. Por. O. Clément, Berdiaeff et le Personalisme français, "Contacts" 67 (1969) 205-228; tenże, L'Église orthodoxe, 63.

31 Clément. L'homme..., art. cyt., 292. Por. na ten temat trafne uwagi Y. Congara, Les chrétiens en dialogue, Paris 1964, 264, 271, 276.

32 Meyendorff, Le Christ..., dz. cyt., 288-289. 
Posługując się głównie pojęciem przyczynowości formalnej wewnętrznej, konstytuującej byt od wewnątrz oraz zewnętrznej czyli wzorczej, antropologia prawosławna uczy, że natura ludzka jest $z$ istoty swej stworzona na obraz boży. Nie może ona byc określona niezależnie od swego wymiaru ,ikonicznego"; nie można definiować jej uprzednio, a ciopiero póżniej - na podstawie Pisma świętego - odnajdywać w człowieku obraz boży. Według tradycji wschodniej rzeczywistość obrazu jest konstytutywna cechą natury ludzkiej jako takiej ${ }^{33}$.

Prawdziwy, doskonaly i ,podobny obraz" zakłada uczestnictwo w przymiotach egzystencji bożej: w duchowości, nieskażoności i nieśmiertelności. W świetle antropologii prawoslawnej nie są to ,dary dodane" (dona superaddita) do natury ludzkiej, która mogłaby być doskonała bez tych darów; należą one w sposób wewnętrzny i istotny do samej natury ludzkiej, w miare jej zgodności z boskim Prawzorem oraz z jej prawda, wewnętrzną. Przebóstwienie, tj. uczestnictwo w energiach bożych, nie jest darem dodanym do natury, którą można by zdefiniować hez tego uczestnictwa, lecz elementem składowym samej natury, gdy odtwarza ona swój model pierwotny.

\section{Prawosławna nauka o stosunku natury i łaski}

U podstaw antropologii prawosławnej znajduje się więc również swoista koncepcja laski i porządku nadprzyrodzonego. Teologia prawosławna nie zna ostrych rozgraniczeń. Podczas gdy tradycja zachodnia bardziej podkreśla różnicę między naturą i łaską, myśl wschodnia akcentuje raczej tajemnicze przenikanie się natury i laski. Natura pojmowana jest jako niepełne i niedoskonałe uczestnictwo w Bogu (zniekształcone przez upadek); łaska realizuje to uczestnictwo w sposób doskonały, ale niejako na przedłużeniu tej samej linii. Rzeczywistość łaski jest swoistym udoskonaleniem i wypełnieniem ontologii człowieka, pogłębiającym wrodzone i konstytutywne podobieństwo do Boga, zawarte już w samej jego naturze.

Tradycja prawosławna nie zna pojęcia nadprzyrodzoności jako daru dodanego do natury stworzonej. Obcą jest dla niej idea łaski stworzonej. Uczy ona jedynie o łasce niestworzonej, tj. o przebóstwiających energiach bożych, wiecznie promieniujących $z$ istoty bożej ${ }^{34}$. Podstawą takiego pojęcia łaski jest dogmat Kościoła prawosławnego o realnej

33 Według Bułgakowa obraz Boży jest ,ens realissimum" w człowieku niezniszczalną, boską podstawą jego egzystencji. Die christl. Anthropologie, dz. cyt., 223.

34 Por. Lossky, Théologie mystique, dz. cyt., 87, 240; Lot-Borodine, dz. cyt., 32; P. Evdokimov, De la nature et de a grâce dans la théologie de l'Orient, w: L'Église et les Eglises 1054-1954, t. II, Chevetogne 1955, 171-195.

Analecta -15 
różnicy między istotą bożą a jej działaniem, czyli energiami ${ }^{35}$. Easką bożą nie jest sama istota Boga, lecz niestworzone i nieodłączne od niej energie, przez które objawia się On stworzeniom, podczas gdy Jego istota pozostaje absolutnie transcendentna, niedostępna i niepoznawalna. Energie te pochodzą od Ojca i udzielają się stworzeniom przez Syna w Duchu świętym. Skutkiem tego łaska przebóstwiająca człowieka jest zjednoczeniem $\mathrm{z}$ energiami, a nie $\mathrm{z}$ istotą bożą; jest darem niestworzonym, nie dodanym do natury ludzkiej, lecz wszczepionym w nią, który sprawia, że człowiek jest obrazem Boga Trójjedynego ${ }^{36}$.

Według teologii prawosławnej, natura ludzka - stworzona na obraz boży - jest teoforyczna od samego początku, łaska zaś jest w pewnym sensie współnaturalna $\mathrm{z}$ naturą; obydwie przenikają się wzajemnie ${ }^{37}$. Nadprzyrodzoność była prawdziwą naturą pierwszego człowieka, a nie czymyś dodanym i zewnętrznym w stosunku do niej; uczestnictwo w życiu bożym jest darem nieodłącznym od samej natury ludzkiej ${ }^{38}$. Teologia prawosławna odrzuca pojęcie ,natury czystej” oraz wszelką dwuwarstwową koncepcję człowieka. Easka pojęta jest w sensie energii bożych, które znajdują się u samych podstaw bytu, są jego początkiem, ośrodkiem i celem ${ }^{39}$.

W konsekwencji, podkreślając ciągłość między naturą (w tym co zawiera ona dobrego i wartościowego) a „nadnaturą", myśl wschodnia bardzo pozytywnie oceniała wszelkie przejawy wartości religijnych poza chrześcijaństwem. W historii powszechnej dopatrywała się ona zjawiska religijnego. Liturgia wschodnia mówi o „,bezpłodnym Kościele pogańskim” " 40. Pogaństwo nazywane jest „kościołem bezpłodnym”; jakkolwiek

35 W r. 1351 synod konstantynopolski uznał tę doktrynę za autentyczny wyraz wiary prawosławnej i za dogmat Kościoła prawosławnego. Rozróżnienie to pojawiło się już u św. Bazylego i Grzegorza z Nysy, z kolei zaś zostało przejęte przez Pseudo-Dionizego Areopagitę, św. Jana Damasceńskiego oraz Grzegorza Palamasa. 36 Lossky, Théologie mystique, dz. cyt., 65-86; tenże, A l'image..., dz. cyt., 34-36, 48; Lot-Borodine, dz. cyt., 32-40 oraz L'anthropologie théocentrique de l'Orient comme base de son expérience spirituelle, „Irénikon” 16 (1939) 6-21, zwł. s. $8,17-18$.

37 Evdokimov, Prawostawie, dz. cyt., 98, 100; Lot-Borodine, La déification, dz. cyt., 189 .

${ }_{38} \mathrm{Za}$ św. Ireneuszem (Adv. haer. 5, 6, 1; PG VII, 1138) teologowie prawosławni często przypominają, że człowiek składa się z ciała, duszy i Ducha Świętego, podkreślając przez to dynamiczny i "otwarty" charakter natury ludzkiej. Por. Meyendorff; Orthodox Theology..., art. cyt., 83-84; Lot-Borodine, La déification, dz. cyt., 41 .

39 Por. Clément, L'homme..., art. cyt., 296. Teologowie prawosławni krytykują katolicką naukę o łasce i sprawiedliwości pierwotnej (pojętych jako ,donum superadditum") zarzucając jej swoisty eksterioryzm, który nie pozwala zrozumieć ontycznego charakteru przebóstwienia człowieka.

40 Zenkowsky, Das Bild..., dz. cyt., 33 przyp. 1, 40 przyp. 2; Evdokimov. Prawosławie, dz. cyt., 106-107; N. Louvaris, Kirche und Welt, w: Die orthodoxe Kirche in griechischer Sicht, Stuttgart 1960, cz. II, 144-154, zwł. s. 146. Por. także Congar, dz. cyt., $278-279$. 
nie przynosi ono żadnego owocu, jest jednakże Kościołem w stanie potencjalnym, nieowocującym. W ten sposób podkreślona jest również idea ciągłości między wszelką prawdą i dobrem naturalnym a porządkiem łaski i zbawienia. W tym sensie Ojcowie wschodni przypisywali np. Słowu Bożemu wszystko to, co po upadku, nawet $\mathrm{u}$ pogan, pozostało z prawdy. Mówią oni o "przygotowaniu” Ewangeli i "nawiedzinach" Słowa przed Wcieleniem wśród tych, którzy nie znali Objawienia, widząc w tym kenotyczny sposób objawiania się Logosu w „kościele pogańskim”.

Właśnie to stanowisko teologiczne wyjaśnia fakt, dlaczego teologowie i filozofowie prawosławni zareagowali ostro przeciwko bartyzmowi wraz z jego pesymizmem antropologicznym i negatywną oceną natury po Wcieleniu ${ }^{41}$.

\section{CHARAKTERYSTYCZNE RYSY ANTROPOLOGII PRAWOSEAWNEJ}

Antropologia prawosławna odznacza się specyficznym ujęciem i podkreśleniem pewnych idei teologicznych dotyczących natury i przeznaczenia człowieka, wskutek czego odróżnia się ona od systematycznej antropologii katolickiej i protestanckiej. Podczas gdy antropologia Kościoła zachodniego posiada przeważnie charakter moralny, antropologia prawosławna odznacza się na pierwszym miejscu swoim charakterem ontycznym. Przejawia się on we wszystkich głównych cechach antropologii prawosławnej.

\section{Antropologia apofatyczna i mistyczna}

W ścisłej korelacji do apofatycznej ,,teologii”, podkreślającej niepojętą tajemnicę Boga, prawosławie rozwija antropologie apofatyczną, która ukazuje tajemnicę istniejącą również w samym człowieku ${ }^{42}$. „Niedostępnej światłości" Boga (1 Tym 6, 16) odpowiada, zdaniem teologów prawosławnych, niezbadana egzystencjalna głębia człowieka, której symbolem jest „serce” (por. Jer 17, 9-10). Misterium „Boga ukrytego” (Iz 45, 15.) posiada swe przedłużenie w tajemnicy ,człowieka ukrytego" (ho kryptós tes kardías ántropos: 1 P 3, 4). W ten sposób apofatycznej „teologii" odpowiada apofatyczna antropologia ${ }^{43}$.

Myśl prawosławna dostrzega w tym najgłębszą rację niewystarczalności wszelkiej czysto ludzkiej filozofii w interpretacji człowieka oraz

41 Por. Bierdiajew, art. cyt., 9; B. Wysiesławcjew, Obraz bożij w suszcziestwie cziełowieka. „Put'” 49 (1935) 66-67 (48-71); Archim. Kiprian. Tema o czietowiekie, art. cyt., 136.

42 Lot-Borodine, La déification..., art. cyt., 26-40; Lossky, Théologie mystique, dz. cyt., 141 .

${ }_{43}$ Evdokimov, Prawosławie, dz. cyt., 75-76; tenże, Mystère..., art. cyt., 282; Clément, L'Église orthodoxe, 61-62; tenże, L'homme..., art. cyt., 292, 301; Nissiotis art. cyt., 25; Lossky, Théologie mystique..., dz. cyt., 113. 
konieczność odwołania się do teologii. Podobnie jak sam Bóg, tak i osoba stworzona nie może być przedmiotem wyczerpującego poznania. Wymyka się ona wszelkiej definicji racjonalnopojęciowej i pozwala się zgłębiać jedynie na drodze poznania intuicyjnego lub też dzięki objawieniu mistycznemu. Apofatycznie można ją określić jako „niesprowadzalność człowieka do jego natury" 44.

Noment apofatyczny w poznaniu człowieka zasługuje, zdaniem N. Nissiotisa, na szczególną uwagę zwłaszcza obecnie, na tle niepoznawalności człowieka przez nauki eksperymentalne. Teologowie nie powinni wyobrażać sobie, jego zdaniem, że z racji Objawienia Bożego posiadają głębsze poznanie człowieka niż reprezentanci nauk szczegółowych, niezdolnych do rozszyfrowania zagadki człowieka. Jeśli nauki te - wysuwając hipotezę za hipotezą - nie są w stanie poznać ostatecznych racji biologicznej egzystencji człowieka, nie można przeciwstawiać im antropologii teologicznej i utrzymywać, że posiada ona giębszy wgląd w tajemnice ludzkiego istnienia. Zadaniem teologii nie jest wypełnienie za pośrednictwem Objawienia luk poznania ściśle naukowego. Jej poznanie mieści się na zupełnie innej płaszczyźnie niż pole badań naukowych; dotyczy ono zupełnie innego wymiaru człowieka, który wcale nie wydaje się konieczny dla nauk eksperymentalnych. Istnieje $\mathrm{w}$ poznaniu człowieka pewien apofatyzm naukowy i apofatyzm teologiczny, ale wiążą się one z dwoma różnymi porządkami poznania. Niepoznawalność czło-. wieka przez nauki szczególowe nie utożsamia się z niepoznawalnośctą czlowieka w teologii. Ta ostatnia ma swoje źródło w fakcie stworzenia egzystencji ludzkiej przez Boga oraz jej przetworzenia w Chrystusie, a więc ostatecznie opiera się na interwencji Boga 45.

\section{Antropologia obrazu Bożego}

Zagadnieniu pochodzenia czlowieka w perspektywie ewolucjonistycz-nej rnyśl prawosławna poświęciła niewiele uwagi, odnosząc się raczej nieufnie do wszelkich hipotez na ten temat ${ }^{46}$. Podkreśla ona przede wszystkim konieczność zachowania istoty nauki biblijnej, $t \mathrm{j}$. uzhania specjalnego aktu stwórczego ze strony Boga, cała natomiast uwagę skupia na ontycznym wyposażeniu człowieka. Z tego punktu widzenia antropologia prawosławna jest par excellence antropologia obrazu Bożego w człowieku.

ct ,... il nous sera impossible de former un concept de la personne humaine et il faudra se contenter de dire: la personne signifie l'irréductibilité de l'homme à sa nature". Lossky, A l'image.., dz. cyt., 118. Por. Clément, L'homme..., art. cyt., 291-292; Evdokimov, Mystère..., art. cyt., 284-285, 288.

t5 Nissiotis, art. cyt., 24-25.

46 Por. Zenkowsky, Das Bild..., dz. cyt., 14-17; Bułgakov, Niewiesta Agnca, dz. cyt., $187-199$. 
Wyeksponowanie dynamicznej rzeczywistości obrazu Bożego w człowieku jest podstawową intuicją antropologii prawosławnej. Odrzuca ona interpretacje pojęcia obrazu w sensie substancjonalnym i statycznym; nie pojmuje go jako ,nadnatury” w człowieku. Obrazem Bożym jest cała osobowa humanitas człowieka wraz z jego duszą i ciałem, rozumem i wclnością, zdolna do świadomego wyboru i przekraczania swojej własnej natury, aby zjednoczyć się z Bogiem. Istota obrazu Bożego polega na prymacie życia duchowego, tj. na dynamicznym nastawieniu całej istoty ludzkiej ku „Boskiemu Archetypowi” (Orygenes), na wytężonym dążeniu (epèktasis) ,ikony" ludzkiej do jej Prototypu ${ }^{47}$.

Teologia prawosławna wprowadza wyraźne rozróżnienie między pojęciem „obrazu” a idea ,,podobieństwa”. Obraz jest elementem dynamicznym. wchodzącym w ontyczną, osobową strukturę czlowieka, natomiast podobieństwo jest $\mathrm{z}$ a d a niem domagającym się realizacji. Stworzony na obraz Boży, człowiek powołany został do urzeczywistniania w sobie podobieństwa Bożego; ze stanu niewinności pierwotnej i bezgrzeszności miał przejść do stanu cnoty i świętości, zdobywanych na drodze współpracy wolnej woli z łaską Bożą. Sam fakt stworzenia człowieka na obraz Boży wzywa i przynagla go ustawicznie do osiągnięcia podobieństwa, tj. ,obrazu podobnego". Jako obiektywna podstawa dynamicznej struktury człowieka, obraz Boży domaga się subiektywnego, osobistego podobieństwa; przejawia się i działa w tym podobieństwie ${ }^{48}$.

Stanowiąc konstytutywny element natury ludzkiej, obraz Boży nie może być nigdy calkowicie utracony; może jednak realizować się w mniejszym lub większym stopniu. Czym innym jest natura prawdziwa, tj. taka jaką Bóg stworzył na początku i którą odnowił w Chrystusie, czym innym natomiast natura ludzka w swoim stanie faktycznym po upadku ${ }^{49}$. Wskutek grzechu obraz Boży został osłabiony i zniekształcony; jest niedoskonały. ponieważ nie jest w pełni ,obrazem podobnym". Utracone zostało podobieństwo, tj. zdolność twórczego i dobrego działania, co z kolei zafałszowało obraz Boży w człowieku i odebrało mu jego prawdziwą skuteczność. Będąc zjawiskiem wtórnym, grzech nie zdołał zniszczyć pierwotnej tajemnicy człowieka; obraz Boży w człowieku, stanowiący konstytutywny element jego natury, jest niezatarty i żadne

47 Evdokimov, Mystère..., art. cyt., 284; Bułgakow, Die christl. Anthropologie, dz. cyt., 224-230; W. Zenkowskij, Ob obrazje bożjem w cziełowiekie, „Prawosławnaja Mysl" 2 (1930) 102-126; Nissiotis, art. cyt., 29. Na temat dwóch zasadniczych tendencji patrystycznych $\mathrm{w}$ interpretacji obrazu Bożego $\mathrm{w}$ czlowieku por. Lossky, Théologie mystique, dz. cyt., $110-111$.

${ }_{48}$ Por. m. in. Karmiris, dz. cyt., 41-42; Lot-Borodine, L'anthropologie, art. cyt., 7; Zenkovsky, Das Bild... dz. cyt., 17; Bulgakow, Die christl. Anthropologie, dz. cyt., 237. Według św. Jana Damasceńskiego jest to podobieństwo w działaniu, w cnocie. De fide orthodox, II, 12; PG 94, 919-920.

49 Por. Zenkovsky, Das Bild..., dz. cyt., 12-14. 
zło nie może go unicestwić: „obrazem jestem niewymownej Twej chwały, chociaż noszę piętna mych grzechów" (troparion prawosławnego nabożeństwa żałobnego, tzw. panichidy) ${ }^{50}$.

Teandryzm osoby ludzkiej, potencjalnie zawarty w samym akcie stworzenia człowieka na obraz Boży, osiąga swą pełnię w człowieczeństwie Chrystusa. Misterium Wcielenia realizuje i ujawnia teandryczną strukturę osoby ludzkiej, taką, jaką Bóg zamierzył na początku, stwarzając ją na obraz Chrystusa jako Prototypu ${ }^{51}$. Odkupienie odnawia w człowieku jego ,przyrodzoną prawdziwość" uzdrawiając i potencjalnie przemieniając całą naturę ludzką. Chrystus przywraca człowiekowi boskie podobieństwo, wyzwalając tym samym jego obraz. Dlatego też według nauki prawosławnej celem chrztu jest odnowienie w człowieku zniekształconego obrazu bożego, podczas gdy bierzmowanie przywraca mu podobieństwo boże 52 .

W opozycji do wszelkich tendencji absolutyzujących autonomię człowieka, antropologia prawosławna podkreśla, że człowiek stworzony na obraz Boży jest istotą ,teomorficzną", teandryczną i teocentryczną ${ }^{53}$. Jego prawdziwe człowieczeństwo realizuje się dzięki otwartości na Absolut, nieśmiertelność i twórczość, ponieważ Bóg stwarzając człowieka na swój obraz, wyszedł naprzeciw tej otwartości ${ }^{54}$. Człowiek jest wolny i posiada zdolność wyboru, ponieważ jest obrazem wolności Boga. Hipostaza ludzka urzeczywistnia się w sposób odpowiedzialny na drodze twórczej wolności i miłości ${ }^{55}$. Stworzeniu człowieka na obraz i podobieństwo Boga, odpowiada wolne ,amo, ergo sum" ze strony człowieka ${ }^{56}$. Realizacja obrazu jest równocześnie realizacją osobowości.

Człowiek jest nie tylko istotą walczącą $z$ grzechem i zbawiającą się, ale również istotą twó r c zą i powołaną do twórczości. Zdaniem N. Bierdiajewa, w twórczej naturze człowieka, w jego podobieństwie do boskiego Twórcy należy szukać istoty obrazu Bożego ${ }^{57}$. W twórczości

50 Por. B. Wysziesławcjew, Obraz bożij $w$ griechopadienii, „Put” 55 (1938) 24-40; Evdokimov, Prawosławie, dz. cyt., 100-103.

51 Clément, L'homme..., art. cyt., 291; S. Verkhowsky, Lehre vom Menschen im Lichte der orthodoxen Theologie, „Evang. Theologie” 11 (1951-1952) 310-323 oraz: Der neue Mensch in Christus, tamże s. 332-343.

52 Por. Evdokimov, Prawostawie, dz. cyt., 310.

53 Tamże s. 99; Clément, L'homme, art. cyt., 290.

54 Meyendorff, Orthodox Theology..., art. cyt., 83; tenże, Le Christ..., dz. cyt., 289. Podkreśla on, że uczestnictwo w życiu i chwale Bożej jest dla czlowieka ,elementem naturalnym" (natural element).

55 Wolność jest istotnym elementem podobieństwa człowieka do Boga; człowiek jest prawdziwie wolny, gdy zachowuje w sobie obraz i podobieństwo Boże. Meyendorff, Orthodox Theology, art. cyt., 83-84.

56 W ten sposób E. A. Baratyński przeciwstawił kartezjańskiemu „cogito, ergo sum" twierdzenie o prymacie serca: „amo, ergo sum", widząc w człowieku prawdziwym ,człowieka z sercem” (homo cordis); por. Bułgakow, Die christl. Anthropologie, dz. cyt., 227.

57 Problema cziełowieka, art. cyt., 9. 
człowiek przekracza i przezwycięża samego siebie, swoje rozdwojenie i najbardziej upodabnia się do Stwórcy. W przekonaniu niektórych myślicieli prawosławnych, tradycyjna antropologia chrześcijańska zwracała dotąd za mało uwagi na tajemnicę człowieka jako twórcy (homo creator) 58 .

W świetle nauki o obrazie Bożym. w człowieku antropologia prawosławna ocenia główny brak antropologii czysto humanistycznej, która niewystarczająco i nie do końca afirmuje człowieka. Twierdzenie o samowystarczalności człowieka jest według niej źródłem poniżania go; prawdziwie wywyższa człowieka świadomość, że jest on obrazem i podobieństwem Bożym, a to właśnie stanowi podstawę dla twórczego, teandrycznego humanizmu chrześcijańskiego ${ }^{59}$.

\section{Antropologia teandryczna}

Opierając się na nauce Ojców greckich, antropologia prawosławna nie koncentruje się na grzechu, naturze upadłej i zbawiającej łasce, lecz na przebóstwieniu człowieka. Idea przebóstwienia jest główną i najbardziej istotną ideą, która przenika antropologię prawosławną od początku do końca. Stworzenie człowieka na obraz Boży miało za cel jego przebóstwienie, tj. uczestnictwo $\mathrm{w}$ rzeczywistościach należących do porządku istnienia samego Boga. Obraz Boży niejako predystynuje człowieka do przebóstwienia. „Theosis” jest ostatecznym celem bytów stworzonych, peìną realizacją podobieństwa Bożego. Dzięki temu prawosławna antropologia obrazu bożego jest równocześnie antropologią przebóstwienia, antropologią teandryczną ${ }^{60}$. Do jej rozwoju przyczyniła się w szczególny sposób rosyjska myśl religijna XIX i XX w., biorąc za punkt wyjścia naukę o tzw. bogoczłowieczeństwie (bogocziełowiecziestwo) ${ }^{61}$.

Główną podstawą idei przebóstwienia człowieka przez laskę niestworzoną jest według teologii prawosławnej prawda o Wcieleniu oraz jego dopełnieniu w tajemnicy Zmartwychwstania Chrystusa. Dzięki osobowemu zjednoczeniu natury boskiej i ludzkiej w Chrystusie oraz jej uwiel-

58 Tamże s. 9, 29; Nissiotis, art. cyt., 29; Bułgakow, Die christl. Anthropologie, dz. cyt., 251, 254; Archim. Kiprian, Tema o czietowiekie, art. cyt., 137.

59 Bierdiajew, Problema cziełowieka, art. cyt., 25; Zender, dz. cyt., 189; Nissiotis, art. cyt., 22; Bułgakow, Die christl. Anthropologie, dz. cyt., 251.

60 Evdokimov, Prawosławie, dz. cyt., 104; Lot-Borodine, La déification, dz. cyt., 36, 40; I. Turcu, Conceptul de „chip” si implicatiile lui soteriologice (Pojęcie obrazu oraz jego implikacje soteriologiczne), "Orthodoxia” 11 (1959) 414-429, zwł. s. 426-429. Por. J. Ternus, Berdiajews "theandrische Anthropologie”, ,Scholastik" 28 (1953) 247-252.

61 Por. W. Solowiew, Cztienija o Bogocziełowieństwie, w: Sobrannyje soczinienija IV, S. Pietierburg 1902; Bierdiajew, Problema cziełowieka, art. cyt., 7-11; tenże, Fiłosofia swobodnego ducha. Problematika $i$ apołogija christianstwa, Paris [brw], t. II, 28-31. Według Bułgakowa „bogocziełowieństwo cziełowieka” oznacza jego zdolność i przeznaczenie do życia w Bogu - do przebóstwienia. Die christlo Antropologie, dz. cyt., 235-236, 240. 
bieniu i przemienieniu przez Zmartwychwstanie, cała natura ludzka została potencjalnie przebóstwiona (przez nią zaś cały kosmos). Rozwinięte przez patrystykę wschodnią twierdzenie św. Ireneusza, iż ,.Bóg stał się człowiekiem, aby człowiek mógł stać się bogiem" 62, stało się złotą regułą antropologii prawosławnej. Twierdzenie to zostało jeszcze bardziej sprecyzowane przez św. Atanazego Aleksandryjskiego, który wprowadził doń moment pneumatologiczny: ,Syn Boży stał się synem ludzkim [...] nosicielem ciała (sacrophoros), aby ludzie [...] stali się synami bożymi [...] nosicielami Ducha (pneumatophoroi)" " ${ }^{3}$. Jako rzeczywisty początek odkupienia i decydujący akt, który zawiera w sobie w zalążku wszystkie inne tajemnice Chrystusa, wcielenie jest niezbędnym warunkiem i podstawą przebóstwienia człowieka ${ }^{64}$.

Idea przebóstwienia i teandryzmu (bogoczłowieczeństwa) posiada przede wszystkim doniosłe znaczenie dla zrozumienia osoby ludzkiej jako hipostazy. Prosopon ludzki rozwija się w ",hipostazę" dzięki całkowitemu przetworzeniu $\mathrm{w}$ istotę ,uchrystusowioną" i ,uduchowioną" za pośrednictwem energii Ducha świętego. Teandryczność potencjalnie zawarta w obrazie znajduje swą pełnię dopiero w hipostazie przebóstwionej. Osobą w pełnym tego słowa znaczeniu jest „osoba bytu przebóstwionego”, czyli jej „osobowy sposób egzystencji teandrycznej” ${ }^{65}$. Człowiek jest prawdziwie i w pełni człowiekiem wówczas, gdy uczestniczy w życiu bożym oraz realizuje $\mathrm{w}$ sobie przebóstwiające podobieństwo do Boga ${ }^{66}$.

Skutkiem swej wolności egzystencja ludzka posiada jednak charakter ambiwalentny: człowiek może zrealizować swe podobieństwo do Boga i wówczas jest on „hipostazą bytu przebóstwionego”, może jednak zatrzymać się w połowie drogi, a nawet stać się „,niepodobieństwem” $\mathrm{i}$ wówczas jest to jedynie indywiduum - prosopon bytu naturalnego (stąd pojęcie bestialoczłowieczeństwa jako antytezy bogoczłowieczeństwa w myśli prawosławnej, zwlaszcza rosyjskiej) ${ }^{67}$.

62 Adv. haer. 5. Praef.; PG 7, 1120. Sformulowanie to powtarzają z kolei św. Atanazy, Grzegorz z Nazjanzu i Grzegorz z Nysy. Por. Lossky, A l'image..., dz. cyt., 95.

${ }_{63}$ De Incarnatione et contra Arianos 8; PG 26, 996.

64 Por. P. Bratsiotis, Das Menschenverständnis in der griechischorthodoxen Kirche, „Theol. Zeitschrift” 6 (1950) 376-382. Podkreślając za Ojcami greckimi rolę wcielenia, teologowie prawosławni nie chcą bynajmniej pomniejszać znaczenia śmierci i zmartwychwstania Chrystusa. Według nich całe misterium Chrystusa tworzy jedną niepodzielną całość, skutkiem czego zmartwychwstanie jest jedynie uwieńczeniem i pełną realizacją tajemnicy wcielenia. Por. Theodorou, dz. cyt., 297-298; Karmiris, dz. cyt., 63-68, 75.

0.3 „L'hypostase ainsi se précise: elle est la personne de l'être déifié, son mode personnel d'existence théandrique", Evdokimov, Mystère..., art. cyt., 287.

60 Clément, L'homme..., dz. cyt., 290; Meyendorff, Le Christ..., dz. cyt., 288, 291.

67 Zenkovsky, Das Bild..., dz. cyt., 17; Evdokimov, Mystère..., art. cyt., 289; Clément, L'homme..., art. cyt., 290. Bulgakow pisze o „zdjableniu” (Verteufelung) człowieka jako o antytezie przebóstwienia. Die christl. Anthropologie, dz. cyt., 237. 
Antropologiczne implikacje idei przebóstwienia przejawiają się szczególnie wyraźnie w powiązaniu z misterium zmartwychwstania Chrystusa i to zarówno $\mathrm{w}$ liturgii 68 jak i w teologii prawosławnej. Ze względu na ,doktrynalne przywiązanie prawosławia do zmartwychwstania" 69 oraz do wczesnochrześcijańskiej perspektywy chrystologicznej stawiającej na pierwszym planie przebóstwienie ciała Chrystusa, a w nim ciała ludzkiego, antropologia prawosławna posiada charakter wybitnie paschalny, rezurekcyjny. Tajemnica zmartwychwstania dopełniającego misterium wcielenia jest obecna w całej antropologii prawosławnej jako jedna z głównych jej podstaw ${ }^{70}$.

Antropologiczne implikacje misterium zmartwychwstania uwidaczniają się już u św. Maksyma Wyznawcy i Jana Damasceńskiego; św. Grzegorz Palamas wyciągnął $\mathrm{z}$ nich daleko sięgające wnioski, głosząc naukę o przemienieniu (metamórphōsis) fizycznej natury człowieka już w tym życiu za pośrednictwem ,światła Taboru", promieniującego z chwalebnego człowieczeństwa Chrystusa. Odtąd nauka ta stanowi trwały dorobek antropologii prawosławnej i występuje u wszystkich myślicieli prawosławnych. Stanowisko to różni się diametralnie od protestanckiej doktryny o wewnętrznej przemianie natury ludzkiej dopiero w czasach eschatologicznych. Posiada ono z kolei wpływ na prawosławną koncepcje ascezy, która zmierza do „prześwietlenia” (proswietlenije) i przeobrażenia (prieobrażienije) natury ludzkiej, aby stała się godną przebóstwienia przez Boga i oglądania go oczyma duszy już tu na ziemi ${ }^{71}$.

W tym kontekście nietrudno zrozumieć, skąd płynie ogromna doniosłość święta Paschy w Kościele prawosławnym. Przeżycie Paschy jest, według wyrażenia B. Zienkowskiego, ,bezpośrednim przeżyciem obrazu Bożego" w człowieku, odnowionego w swej doskonałości przez męke, śmierć i zmartwychwstanie Chrystusa ${ }^{72}$. Chrystus przyszedł na świat, aby zniszczyć śmierć i odnowić człowieka na swój obraz; przez swoją śmierć zwyciężył On naszą śmierć i potencjalnie przebóstwił całą naturę ludzką jako Nowy Człowiek - Nowy Adam ${ }^{73}$.

Proces przebóstwienia człowieka, pojęty jako uczestnictwo w ożywiającej mocy Chrystusa zmartwychwstałego (por. 1 Kor 15, 45), przedłuża

68 Por. Troparion paschalny oraz kanon paschalny św. Jana Damasceńskiego.

69 O. Rousseau, Incarnation et anthropologie en Orient et en Occident, "Irénikon" 26 (1953) 369, 363-375.

70 Tamże s. 369, 373. Bułgakow uważa, że również Maryja jest doskonałą realizacją bogoczłowieczeństwa; w niej dokonało się uwielbienie człowieka i przemiana stworzenia. Die christl. Anthropologie, dz. cyt., 241-242.

71 Przykładem tego typu ascezy jest św. Serafin z Sarowu; w literaturze postać starca Zosimy w Braciach Karamazow F. Dostojewskiego.

${ }_{72}$ Das Bild..., dz. cyt., 10-11. Por. Lot-Borodin, La défication..., dz. cyt., 55.

73 Taka jest soteriologiczna dominanta Wschodu chrześcijańskiego. Akcent położony jest przede wszystkim na wyzwolenie przez odrodzenie, a nie jak w teologii zachodniej - na pojednanie względnie odpuszczenie grzechów. Por. Lot-Boridin, La déification, dz. cyt., 54-57; Karmiris, dz. cyt., 75-77. 
się w Kościele. W ten sposób pozostając w ścisłej więzi z soteriologią, antropologia prawosławna dopełnia się $\mathrm{w}$ eklezjologii. W perspektywie antropologii przebóstwienia Kościół jest miejscem przebóstwiającej przemiany człowieka przez sakramenty i kult, organizmem teandrycznym, w którym działają energie przebóstwiające i gdzie człowiek staje się współpracownikiem Boga (1 Kor 3, 9). Za pośrednictwem Kościoła realizuje się nie tylko indywidualny obraz Boży w człowieku, lecz również obraz kolektywny, eklezjalny, a nawet kosmiczny. W Kościele człowiek znajduje swój prawdziwy wymiar „katolicki”, w powiązaniu z całą ludzkością i kosmosem ${ }^{74}$.

\section{Antropologia eschatologiczna}

Eschatologiczny charakter antropologii prawosławnej wynika już $\mathrm{z}$ samego faktu, że dominuje $\mathrm{w}$ niej idea zmartwychwstania. Problem dziejów, zła, cierpienia i śmierci człowieka rozpatruje ona w świetle zwycięstwa zmartwychwstania Chrystusa oraz nadziei zmartwychwstania powszechnego ${ }^{75}$. Nadzieja chrześcijańska jest $\mathrm{w}$ niej, na równi $\mathrm{z}$ wiarą, źródłem poznania tajemnicy człowieka jako wyraz swoistego „spero ut intelligam". W tym sensie antropologia prawosławna jest antropologią eschatologiczną, zbudowaną nie tylko w perspektywie przeszłości, ale również w perspektywie przyszłości ${ }^{76}$.

Eschatologiczna orientacja antropologii prawosławnej rosyjskiej uwidoczniła się w XIX w. szczególnie u N. Fiodorowa (1823-1903) ${ }^{77}$, natomiast w XX w. u S. Bułgakowa ${ }^{78}$ i N. Bierdiajewa ${ }^{79}$. W ujęciu tych myślicieli prawosławnych eschatologizm antropologiczny posiada charakter aktywny i twórczy; nacechowany jest on maksymalistycznym wartościowaniem człowieka i głębokim optymizmem antropologicznym, co odróżnia go zdecydowanie od pesymistycznych tendencji myśli protestanckiej. Ujawnia się to szczególnie w ocenie sensu dziejów ludzkich oraz wartości doczesnego postępu człowieka. W tym punkcie antropologia prawosławna wiąże się ściśle z teologią i filozofią dziejów ${ }^{80}$.

74 Clément, L’homme..., art. cyt., 293; Nissiotis, art. cyt., 30.

75 Por. Zenkowsky, Das Bild..., dz. cyt., 53-68; Bierdiajew, Problema cziełowieka, art. cyt., $19-20$.

76 Bierdiajew, Problema cziełowieka, art. cyt., 24.

77 Powolaniem ludzkości jest według Fiodorowa przezwyciężyć śmierć i przyspieszyć triumf życia. Fiłosofia obszczego dieła, Moskwa 1913. Od niego zaczerpnął Bierdiajew ideę ludzkiej twórczości.

78 Według Bułgakowa myśl o realizacji Królestwa Chrystusa na ziemi przez twórczą działalność człowieka w historii jest istotnym rysem antropologii prawosławnej oraz centralnym tematem rosyjskiej mysli religijnej. Die christl. Anthropologie, dz. cyt., 248, 252; O carstwii bożjem, „Put"” 11 (1928) 3-30.

79 Zagadnieniu twórczości ludzkiej poświęcił Bierdiajew jedno ze swoich pierwszych dzieł: Smysz tworcziestwa. Opyt oprawdanija cziełowieka, Moskwa 1916.

80 Bierdiajew, Problema cziełowieka, art. cyt., 23-24; Bułgakow, Die christl. Anthropologie, dz. cyt., 248-254. 
Ponieważ człowiek stworzony na obraz i podobieństwo Boże jest twórcą, jego powołaniem jest - zdaniem S. Bułgakowa - „uczłowieczać" świat, ustawicznie ,nadawać mu imię ludzkie”, przekształcać go, tworzyć kulturę, realizować królestwo dobra i piękna ${ }^{81}$. Eschatologiczne wypełnienie dziejów ludzkich jest odpowiednikiem dzieła stworzenia, jego uwieńczeniem i urzeczywistnieniem celów, które Bóg zamierzył na początku stwarzając człowieka na swój obraz.

Głosząc naukę o przeobrażeniu i uwielbieniu całego stworzenia, antropologia prawosławna pojmuje tę przemianę nie jako owoc doczesnej aktywności ludzkiej, lecz raczej jako skutek zstąpienia i manifestacji tego co boskie w rzeczywistości ziemskiej. Tym należy tłumaczyć fakt, dlaczego, pomimo swego charakteru wybitnie kosmicznego, prawosławie nie rozwinęło w tym stopniu co myśl zachodnia nauki o doczesnym zaangażowaniu i działalności człowieka w świecie. Odrodzenie całej natury, jako preludium stworzenia ,nowych niebios i nowej ziemi", rozpoczyna się przebóstwieniem poszczególnego człowieka. Według tradycyjnej nauki prawosławnej kosmos należy nie tyle opanowywać, ile raczej przede wszystkim przeobrażać i przemieniać przez łaskę. Skutkiem tego również świętość prawosławna realizowała się zazwyczaj w formie monastycznej ucieczki od świata, a humanizm prawosławny posiadał przeważnie charakter monastyczny ${ }^{82}$. U współczesnych myślicieli prawosławnych coraz częściej zaznacza się tendencja do podkreślania potrzeby ,twórczego humanizmu chrześcijańskiego”. Pojmują go oni jako „,twórczość w imię Chrystusa, natchnioną przez Ducha świętego", budującą Królestwo Boże i przygotowującą paruzję w historii ${ }^{83}$. Działanie ludzkie nie usuwa ani nie pomniejsza działania Bożego w świecie, które prowadzi do eschatologicznego wypełnienia dziejów. Historyczne osiągnięcia człowieka, jakkolwiek ograniczone i względne, przeniknięte są równocześnie działaniem Bożej mocy. W ten sposób tradycyjnie podkreślana przez prawosławnych linia zstępująca działania Bożego jest uzupełniona zaakcentowaniem wstępującej linii działalności ludzkiej ${ }^{84}$.

Z drugiej strony współczesna antropologia prawosławna dostrzega również niebezpieczeństwa wynikające z utożsamienia nadziei teologalnej $z$ czysîo ludzkim optymizmem futurologii antropologicznej, opartym

81 Bułgakow, Die christl. Anthropologie, dz. cyt., 219-221, 253-254.

82 Tamże s. 235-236; Louvaris, dz. cyt., 145-147.

83 Bułgakow, Die christl. Anthropologie, dz. cyt., 251-252. „Humanism is false and dangerous when it claims to supersede Christ and makes itself into a religion. But when it is simply an expression of natural human kindness created by God and sanctified by christianity, it has as much place in the life of the Church as bread and wine used for the eucharist, or water necessary for baptism". Zander, dz. cyt., 189.

$84 \mathrm{~W}$ poglądach Bułgakowa pomostem jest jego nauka o ,sofijnej naturze człowieka" (sophienhafte Wesen des Menschen). Die christl. Anthropologie, dz. cyt., 221, 229, 239, 250, 254. Por. także Louvaris, dz. cyt., 150-152. 
na wierze $\mathrm{w}$ udoskonalenie człowieka przy pomocy jego własnych sił. Teologowie prawosławni zwracają uwagę, że jakkolwiek nadzieja chrześcijańska nie przekreśla słusznej autonomii człowieka ani postępu ludzkiego, opiera się ona jednak na eschatologicznej wizji przyszłości. Z istoty swej jest ona eschatologiczna; nie ma nic wspólnego $z$ utopizmem ani z pragmatyzmem antropologicznym ${ }^{85}$.

W świetle antropologii prawosławnej tajemnica człowieka zawarta jest nie tylko $w$ jego strukturze ontycznej (obraz Boży, relacja do innych ludzi, a przez ciało zależność od kosmosu), nie tylko w ambiwalentnej dynamice jego życia (dar wolności, skłonność do zła, arytmia dążeń), lecz wyraża się również w samym zadaniu, do którego urzeczywistnienia człowiek jest powołany (przebóstwienie). W przekonaniu prawosławnych, teologia może być i w pewnym sensie jest antropocentryczna; sam człowiek jednak nie jest bynajmniej bytem antropocentrycznym, lecz istota teocentryczną, powołaną do osobowego uczestnictwa w życiu Bożym i do zjednoczenia z Bogiem.

Sposób myślenia o człowieku w tradycji wschodniej jest pod wieloma względami różny od sposobu pojmowania człowieka w teologii zachodniej. Są to de facto dwie różne antropologie, w których przejawia się na swój sposób nierozwiązana do dziś dychotomia natury i łaski, immanencji i transcendencji ${ }^{86}$. Antropologia prawosławna uwrażliwiona jest bardziej na porządek bytu; posiada ona charakter ontyczny, pojmuje naturę ludzką w sposób religijny i mistyczny, podkreślając jej funkcję teoforyczną, wynikającą z ontologii obrazu Bożego w człowieku. Kształtuje się ona $w$ atmosferze misterium człowieka i kontempluje je w jego wielorakich wymiarach. W porównaniu $z$ nią antropologia zachodnia posiada raczej charakter moralny; ujęta jest przede wszystkim $\mathrm{w}$ perspektywie działania natury ludzkiej, skierowanej do celu ostatecznego i zdobywającej ten cel przy pomocy dobrych czynów. Różnice powstałe między antropologią wschodnią i zachodnią są, zdaniem Y. Congara, w dużej mierze rezultatem wiekowej opozycji między myślą platońską i arystotelesowską ${ }^{87}$. $249-250$.

85 Nissiotis, art. cyt., 26-27; Bulgakow, Die christl. Anthropologie, dz. cyt.,

${ }_{86}$ Wewnętrzna struktura obydwu antropologii posiada $z$ kolei wpływ na cały szereg innych zagadnień teologicznych i filozoficznych. Por. na ten temat uwagi Congara, dz. cyt., 267-270, 282-285.

87 Congar, dz. cyt., 265-266, 268, 271, 275. Zaznacza on, że błędnym byłoby jeđnak twierdzenie, iż Zachód poszedł za Arystotelesem, a Wschód za Platonem; na Wschodzie byli myśliciele, którzy czerpali $z$ Arystotelesa ( $m$. in. św. Jan 
W porównaniu z zachodnią koncepcją człowieka, zwłaszcza protestancką, antropologia prawosławna odznacza się nieporównanie większym optymizmem. Widzi ona w czlowieku nie ,sluge i niewolnika grzechu", w którym nie ma ,żadnego wdzięku ani piękności" ${ }^{88}$, lecz w ślad za Ojcami Kościoła - partnera i współpracownika Bożego, który jest „chwałą Boga" i „chwalą Chrystusa" ${ }^{89}$, istotą powołaną do przebóstwiającego uczestnictwa w życiu Bożym już tu na ziemi. Ta istotna idea antropologii prawosławnej nadaje swoisty ton całej teologii i duchowości prawosławnej.

W oczach teologa protestanckiego, a nawet katolickiego, prawosławna koncepcja czlowieka może wyc̉awać się czasem za bardzo idealna i zbyt optymistyczna ${ }^{30}$. Rozwinęła się ona w atmosferze kultury sakralnej, którą kształtowała i rozwijała. Obecnie, w epoce wzmagającej sie sekularyzacji i modernizacji, również przed nią pojawia się pytanie, czy okaże się na tyle silną w swym oddziaływaniu, aby mogła skutecznie kształtować życie człowieka współczesnego. Wydaje się, że musi ona zwrócić więcej uwagi niż dotąd na dziedzinę ludzkiego działania w świecie, na zaangażowanie i odpowiedzialność chrześcijanina za kształtowanie rzeczywistości doczesnej.

Nietrudno dostrzec, jak wielkie znaczenie dia teologii i dialogu ekumenicznego mógłby mieć żywy i wzajemny kontakt tradycji wschodniej $\mathrm{z}$ tradycją zachodnią $\mathrm{w}$ dziedzinie antropologii. Zasada komplementarności musi znaleźć również tutaj swoje zastosowanie. „Nie na darmo świat chrześcijański posiadał od początku swój Wschód i swój Zachód... Teologia jest $\mathrm{w}$ pełni katolicka jedynie wtedy, gdy na wzór zdrowego organizmu głęboko oddycha i utlenia się przy pomocy swoich obydwu płuc" ${ }^{91}$.

z Damaszku, Georgios Pachymer, Grzegorz Akindynos, Nicefor Gregoras), na Zachodzie zaś istnialy tendencje platonizujące (egzemplaryzm św. Augustyna, Bonawentury, szkoły franciszkańskiej, św. Bernarda).

${ }^{88} \mathrm{~W}$ Probationes Conclusionum dysputy heidelberskiej (1518) Luter pisal o czlowieku: ,... est captivum et servum peccato, non quod sit nihil, sed quod non sit liberum, nisi ad malum" oraz ,... nulla in nobis est species neque decor, sed vivimus in abscondito Dei (id est in nuda fiducia misericordiae eius)". Cyt. za K. Onasch, Einführung in die Konfessionskunde der orthodoxen Kirchen, Berlin $1962,240$.

89 "Gloria enim Dei vivens homo". św. Ireneusz, Adv. haer. IV 20 7; PG 7, 1037. "Twą chwałą, Chryste, jest człowiek...", św. Grzegorz z Nazjanzu PG 37, 1327.

90 "For. Onasch, dz. cyt., 239-240; Congar, dz. cyt., 286.

$\$ 1$ "Ce n'est pas en vain que, dès les origines, le monde chrétien a comporté un Orient et un Occident: il y a là comme un trait imprescriptible de son type providentiel. La théologie n'est pleinement "catholique" que quand, à l'instar d'un organisme sain, elle respire profondément et s'oxygène par ses deux poumons". Congar, dz. cyt., 287. 


\section{L'ANTHROPOLOGIE ORTHODOXE CONTEMPORAINE}

\section{R E S U M E}

L'Eglise orthodoxe ne connaît pas une distinction nette entre l'anthropologie théologique et l'anthropologie philosophique. Depuis un siècle certains penseurs orthodoxes, surtout russes, ont essayé d'élaborer une synthèse anthropologique dans l'esprit d'une fidélité créatrice à la doctrine des Pères grecs (N. Fedorov, V. Soloviev, V. Nesmelov), et une anthropologie théandrique étroitement liée à la christologie (N. Bierdiaev, S. Frank, S. Boulgakov); ils se sont rendu compte que la doctrine traditionnelle sur l'homme doit être repensée sous la lumière des nouveaux problèmes (B. Zenkovsky, V. Lossky, N. Nissiotis, P. Evdokimov, O. Clément). Ả la base de l'anthropologie orthodoxe on retrouve le dogme trinitaire et le dogme christologique, une conception orientale de la causalité et de la participation et une doctrine spécifique sur la relation de la nature et de la grâce, où la grâce est toujours conçue comme la grâce incréée et "connaturelle" à la nature. Parmi les traits les plus remarquables de l'anthropologie orthodoxe l'auteur soulève son caractère apophatique et mystique, sa dimension ,icônique" (l'homme créé à l'image et à la ressemblance de Dieu), théandrique (l'idée de la divino-humanité de l'homme), pascale, optimiste et eschatologique. Pour l'Orient, la première considération dans l'anthropologie est celle de la divinisation entrevue surtout par le fait de l'incarnation et celui de la résurrection du Christ; la divinisation, essentiellement liée au Christ ressuscité. Il s'ensuit que l'idée de la résurrection et elle est toujours présente à l'anthropologie orientale. Le mystère de la personne humaine se manifeste par son ouverture et son aptitude à la transcendance. Pendant que l'anthropologie de l'Eglise occidentale se caractérise par sa dimension morale, celle de l'Église orientale se distinque par son caractère ontologique; elle insiste beaucoup sur le mystère de l'homme comme l'être théocentrique, libre, créateur et appelé à la création. Parce qu'elle se formait dans une atmosphére beaucoup plus sereine et optimiste que celle de l'Eglise d'Occident, elle pourrait apporter au dialogue oecuménique sur l'homme ses propres intuitions religieuses. 